\title{
O destino indelével do desejo: o sonho do amor plural entre anarquistas libertários
}

\author{
Maria Bernardete Ramos Flores ${ }^{1}$ (iD 0000-0002-9438-031X \\ 'Universidade Federal de Santa Catarina, Florianópolis, SC, Brasil. \\ 88.040-900-ppghst@contato.ufsc.br
}

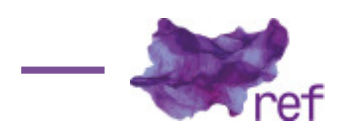

Resumo: O artigo aborda o tema do amor livre e da liberdade sexual contemplado pelo anarquismo libertário, nos anos de 1920 e 1930. Um debate revelador deu-se na revista espanhola Estudios, sob o protagonismo da brasileira Maria Lacerda de Moura. Ela combateu a camaraderie amoureuse proposta por Émile Armand, e defendeu o 'amor plural', mais fraternal que sensual, seguindo o neo-estoicismo de Han Ryner. A causa em comum foi o combate ao casamento indissolúvel, razão da posse, do exclusivismo sexual, do ciúme, da dominação masculina e da escravização da mulher. A exigência da monogamia era tida como prejudicial ao indivíduo, cerceado no direito natural ao prazer e na livre expansão do desejo. A ideia de amor livre e de liberação sexual apontou para uma nova sensibilidade amorosa e novos acordos éticos. O desafio geral: aliar a natureza biológica do sexo aos deslocamentos incessantes do desejo.

Palavras-chave: amor livre; liberdade sexual; anarquismo libertário; feminismo.

Desire and its Indelible Destiny: The Dream of Plural Love among Libertarian Anarchists Abstract: The article deals with the theme of free love and sexual liberation as contemplated by libertarian anarchism in the nineteen twenties and thirties. A revealing debate took place in the Spanish magazine Estudios, under the leadership of the Brazilian writer Maria Lacerda de Moura. She condemned the camaraderie amoureuse proposed by Émile Armand, and defended the more fraternal than sensual 'plural love', following Han Ryner's neo-stoicism. The common cause was the struggle against indissoluble marriage, the reason for possession, sexual exclusiveness, jealousy, male domination, and the enslavement of women. The demand for monogamy was considered damaging to the individual, constrained in the natural right to pleasure and the free expansion of desire. The idea of free love and sexual liberation pointed to a new loving sensitivity and to new ethical agreements. The general challenge was to combine the biological nature of sex with the continuous displacements of desire.

Key words: Free love; Sexual liberation; Libertarian anarchism; Feminism.

\section{Introdução}

O amor é um dos aspectos da vida, e o mais difícil de definir, porque os pontos de vista dos quais pode ser considerado são muito diversos. O amor está situado 'além do bem e do mal'.' (Émile ARMAND, 2000, p. 46).

E é difícil assumir o controle, gerenciar, calcular a natureza multifacetada do fluxo que leva dois ou mais corpos a se unirem com a mesma força inesperada e descontrolada da paixão. ${ }^{2}$ (Osvaldo BAIGORRIA, 2006, p. 11).

Um debate revelador sobre amor livre e liberdade sexual, que produz alguma ressonância no que hoje estamos designando como 'poliamor', deu-se entre anarquistas libertários, no começo

\footnotetext{
1 "El amor es uno de los aspectos de la vida, y el más difícil de definir, porque son muy diversos los puntos de vista desde los cuales se puede considerar. El amor se sitúa 'más allá del bien y del mal'." Todas as traduções, do espanhol e do francês para o português, são livres e da própria autora.

2 "Y es difícil llevar la rienda, manejar, calcular la polifacética naturaleza del flujo que lleva a dos o más cuerpos a unirse o apartarse con la misma inesperada e incontrolada fuerza pasional."
} 
do século XX. O protagonismo da brasileira Maria Lacerda de Moura chama atenção pela importância internacional que o tema adquiriu. Ela rebateu o lema "todos para todas e todas para todos" da proposta do anarquista francês Émile Armand, e defendeu um pluralismo amoroso, mais fraternal que sensual, sob os princípios neo-estoicos do libertário franco-argelino Han Ryner.

Maria Lacerda de Moura (1887, Manhuaçu/MG - 1945, Rio de Janeiro/RJ) é considerada uma das mais destacadas escritoras libertárias no Brasil. ${ }^{3}$ Entre 1928 e 1937, integrou-se à comunidade de Guararema, uma colônia à beira do rio Paraíba, em São Paulo, formada por anarquistas e objetores da consciência, desertores da Primeira Guerra Mundial, italianos, espanhóis e franceses, e que tinham como lema a livre associação e a defesa da vontade do indivíduo. Colaborou em diversos jornais anarquistas, no Brasil, Argentina e Espanha. Neste último país ela se tornou uma das maiores colaboradoras estrangeiras da Estudios (Valencia, Espanha, 1928-1937), a revista "mais transcendente e prestigiosa do anarquismo espanhol" (Xavier DIEZ, 2007, p. 35), anticlerical, pacifista e defensora da liberdade sexual; caracterizava-se como revista eclética, mas tomava posição clara favorável ao neomalthusianismo, ou à natalidade consciente, que desde o começo do século introduzia-se nos meios anarquistas espanhóis, principalmente sob a influência francesa.

Como livre-pensadora, anarco-individualista, feminista-libertária, foi assim que os companheiros espanhóis a reconheceram. Maria Lacerda sustentou acaloradamente o debate sobre amor livre que, entre os anarquistas servia para combater o matrimônio monogâmico e indissolúvel, considerado esteio do Estado, governo da economia, da formação de mão de obra assalariada e do exército, e da lgreja, governo das almas. De modo geral o anarquismo combateu a autoridade, a propriedade e a exploração do trabalho, com estratégias revolucionárias consoantes às respectivas orientações políticas, como anarco-sindicalista, anarco-comunista, anarco-individualista, esta última chamada também de libertária. Para o neo-estoico Han Ryner, o individualismo é uma doutrina moral que, não se apoiando em nenhuma tradição, em nenhuma vontade exterior, não se dirige senão à consciência individual, na busca da vontade de harmonia (RYNER, 2012b). Para um individualista mais prático como Émile Armand, o indivíduo deve ignorar tudo o que possa interferir em sua liberdade e em sua busca de prazer, sob uma ética que exige um exercício de subversão permanente, contra o estabelecido, especialmente, contra a moral cristã, fundamentada no sacrifício e na renúncia (ARMAND, 2007; ARMAND, 2004; ARMAND, 1934a).

Os libertários introduziram as noções de comunidade amorosa, de companheirismo afetivo, de amizade, de fraternidade, da capacidade de amar a várias pessoas sucessiva e simultaneamente, o que aponta para uma nova educação sentimental. Era incoerente para o anarquista libertário aceitar que em nome do amor, o ser humano exercesse poder sobre a pessoa amada, e esta, por sua vez, se submetesse à posse. A defesa da liberação sexual e o combate às leis restritivas e repressivas eram proclamadas de acordo com o seguinte princípio: é legítima a atração sexual como força instintiva, fonte de saúde e de prazer, considerando-se a natureza biológica do sexo e, ao mesmo tempo, os deslocamentos incessantes do desejo. Os libertários pregaram também o nudismo, o naturismo, o vegetarianismo. Afastar-se da natureza é manchar o corpo e a alma, profanar a beleza do amor, matar as aspirações de liberdade.

Contudo, é nesse princípio que se podem explicar as contradições e as controvérsias que os libertários enfrentaram na defesa da liberdade sexual. Em primeiro lugar, o discurso anarquista, em decorrência da defesa de um 'essencialismo' da natureza humana, inclusive a natureza da sexualidade humana, centrou seu discurso na defesa da heterossexualidade; com base na observação da não homossexualidade entre os animais, a homossexualidade humana era vista como desvio de comportamento, por vício ou por problemas congênitos. Em segundo, melhorar a condição de vida da classe obreira, que era um dos propósitos do movimento, requeria cuidado com a geração da prole; o anarquismo, de modo geral, e também os libertários abraçaram uma das grandes crenças à época: a melhoria da espécie humana, pela fé na eugenia, pregando a higiene das famílias, a maternidade consciente, a educação sexual para evitar doenças venéreas e 'taras' sexuais. A eugenia tornou-se uma espécie de porta voz do discurso da sexualidade saudável, ou seja, muitas das concepções sobre a natureza da sexualidade humana e sobre o que é normal ou desviado acabaram por erigir-se em discurso regulador da sexualidade também entre os libertários que pregavam o amor livre.

Aqui, vamos abordar o debate sobre a construção teórica do amor livre, nas décadas de 1920 e 1930, com o protagonismo da brasileira Maria Lacerda de Moura. Ela juntou-se a Armand no combate ao casamento monogâmico e a exclusividade sexual; ambos defenderam a maternidade consciente e propagaram as leis malthusianas. Mas ela rebateu a proposta

\footnotetext{
${ }^{3}$ Embora o número de mulheres no movimento anarquista seja inferior ao dos homens, não significa que elas não se fizeram presentes e atuantes. A Revista Anarquista Aurora Obreira (2005) informa que Edgar Rodrigues registrou 52 mulheres que tiveram relevância especial no movimento social entre as últimas décadas do século XIX e primeiras do XX, no Brasil. Constatamos que na obra Os libertários Rodrigues (1988) apresenta biografias resumidas de algumas mulheres que se destacaram no movimento anarquista: Maria Lacerda de Moura, Isabel Cerrutti, Maria Angelina Soares, Maria Valverde Silvello, Matilde Magrassi e Sofia Garrido.
} 
armandista de 'amor livre', e defendeu o 'amor plural', seguindo seu mestre Han Ryner, que "preconiza o pluralismo amoroso e não aceita a tese do comunismo amoroso que difunde E. Armand em seu periódico l'En-Dehors." ${ }^{4}$ (MOURA, 1934b, p. 25).

Han Ryner (Ghazaouet, Argélia, 1861 - Paris, 1938), pseudônimo de Jacques Élie Henri Ambroise Ner, foi uma das figuras mais destacadas e reconhecidas no panorama da cultura libertária no primeiro terço do século XX. Pacifista, comparado a Gandhi, defendeu a objeção de consciência, a não colaboração e os meios não violentos de ação. Engajado politicamente contra as injustiças, destacou-se em múltiplas campanhas solidárias, dentre as quais se destacam as organizadas para evitar o assassinato dos anarquistas italianos Sacco e Vanzetti, e também em favor do guerrilheiro ucraniano libertário Nestor Makhno. Subiu aos tribunais para testemunhar a favor de objetores, a exemplo de Georges Chevé, encarcerado e julgado pelo Conselho de Guerra, da França, por se negar ao serviço militar obrigatório (MOURA, 1927). Embora tivesse mantido com Armand uma relação pessoal prolongada e contato assíduo (DIEZ, 2007), e estado ao lado dele em campanhas pela defesa da objeção de consciência, Ryner marca sua diferença no que tange à ideia de 'amor livre', fazendo a prédica do 'amor plural', o Eros polyphallique, que prosperou ao ar livre no Panteão da República de Platão (RYNER, 1927).

Émile Armand, pseudônimo de Ernest Juin (Paris, 1872 - Ruão, 1963), outro importante teórico do anarquismo libertário francês, foi um dos maiores entusiastas partidários do amor livre, cuja proposta evoluiu na década de 1920, em parte por meio de discussões e correspondências com os leitores de seu jornal L'En-Dehors (1922-1939) de Paris. Armand teve suas ideias amplamente acolhidas na Espanha, principalmente, na Revista Blanca (Barcelona, 1923-1936) dirigida pela família anarquista de Urales. Armand defendeu a experiência de colônias, onde se praticasse a camaraderie amoureuse, formadas por grupos de casais sob o lema 'todos para todas e todas para todos'. Sua proposta teve seguidores, contudo, rendeu forte polêmica com outros libertários. Um grande contraponto veio de Maria Lacerda, que pregou uma concepção de amor mais espiritual que carnal, mais divina que sensual. Se, para Armand, a razão do ciúme e do exclusivismo sexual estava no amor, para Lacerda, o problema estava no sexo. O debate revelou-se na Estudios, sustentado em boa parte pela representante brasileira. Estudios consignava-se como a nova fase da revista Generación Consciente, fundada em 1923, um nome que, no momento em que o governo espanhol legislava para punir o controle da natalidade, levou seus editores a substituí-lo por outro menos explícito - Estudios: educación sexual, arte, ciência, cultura general -, que, ao fim e ao cabo, dava continuidade ao programa originário: luta contra a ignorância em matéria de sexo, combate à prostituição e prevenção de doenças venéreas; defesa da liberdade feminina e da maternidade consciente; propaganda neomalthusiana (Richard CLEMINSON, 1995).

\section{A camaraderie amoureuse}

Por liberdade do amor, amor livre, amor em liberdade, liberdade sexual, entendo a liberdade total para uma ou um companheiro de amar um, uma ou vários outros simultaneamente (sincronicamente, caso seu determinismo particular o impulsione ou incite a isso). (ARMAND, 2012, p. 23).

O individualismo que Armand apregoava era inspirado em Stirner (ARMAND, 2003) que, segundo ele, dera início à remoção de todos os pilares ou todos os ideais sobre os quais se edifica a sociedade contemporânea: "Deus, Estado, Igreja, religião, causa, moral, moralidade, liberdade, justiça, bem público, abnegação, sacrifício, lei, direito divino, direito do povo, piedade, honra, patriotismo, justiça, hierarquia, verdade, em uma palavra, os ideais de todos os tipos." ${ }^{5}$ (ARMAND, 1934a, p. 781). Ao derrotarmos todos esses fantasmas, emboscados na nossa mentalidade, o Eu se tornaria livre em busca do prazer, razão da vida.

Os fundamentos teóricos da proposta armandista de amor livre e liberdade sexual eram bebidos nos socialistas utópicos, principalmente em Fourier que havia proposto a experimentação por parte do indivíduo de todas as formas possíveis de amor e de associação. $O$ anarquismo libertário se quisesse ser coerente consigo mesmo, segundo Armand, não poderia evitar essa solução, posto que tem por princípio não estabelecer hierarquias entre os prazeres, "[...] nem distinções qualitativas entre as aspirações dos diversos apetites humanos." (ARMAND, 1935, p. 835). O prazer é entendido como objetivo final da vida humana, portanto o amor deveria se manifestar em todas as formas possíveis, com direitos iguais para homens e mulheres. Toda paixão natural, quando cerceada, produz um efeito negativo e nocivo à vida humana. Tudo vale para obter prazer. O estatismo das relações sexuais é a monopolização da vida dos habitantes em

\footnotetext{
4 "Han Ryner preconiza el pluralismo amoroso y no acepta la tesis del comunismo amoroso que difunde E. Armand en su periódico L'En Dehors."

5 "Dios, Estado, Iglesia, religión, causa, moral, moralidad, libertad, justicia, bien público, abnegación, sacrificio, ley, derecho divino, derecho del pueblo, piedad, honor, patriotismo, justicia, jerarquía, verdad, en una palabra, los ideales de toda especie."

6 "[...] ni distinciones cualitativas entre las aspiraciones de los diversos apetitos humanos."
} 
benefício do Estado (ARMAND, 1935). Nesse sentido, a família burguesa, por se arrogar o direito sobre o prazer, é extremamente prejudicial ao indivíduo (ARMAND, 1927).

Tradutor de Wilhelm Reich, psicanalista, considerado revolucionário do sexo, e leitor de Alexandra Kollontai, que por sua vez considerava que a humanidade vivia sob o signo da paixão, sempre ávida por devorar uns aos outros, Armand considerava que era hora de se inventar uma nova forma de amor. Na prática do amor livre, o anarquista individualista, através do "pluralismo amoroso" poderia conquistar "[...] a faculdade de amar pluralmente, em sua tríplice forma intelectual, sentimental e carnal."7 (ARMAND, 2000, p. 63), deixando para trás o ciúme e o desejo de posse, eliminando o ciúme, "a monopolização dos órgãos sexuais e táteis, da pele e da sensação de um ser humano para o benefício de outro, exclusivamente.". (ARMAND, 1935, p. 834). Seria incoerente ocupar-se dos problemas sociais e esquecer os estragos "[...] desse terrível flagelo social que são os ciúmes sexuais na humanidade"9 (ARMAND, 1935, p. 834), que produzem assassinatos em meio a acessos de furor. Tal como a fome é saciada com a abundância de comida ou tal como a sede de cultura é saciada com abundância de livros, o ciúme poderia ser sanado pela abundância sexual.

No amor, como em tudo o mais, é a abundância que aniquila o ciúme e a inveja. Eis por que a fórmula do amor em liberdade, de todos para todas, de todas para todos, é conclamada para ser a favorita do meio anarquista. ${ }^{10}$ (ARMAND, 1935, p. 835).

Contudo, Armand alertava que "[...] liberdade da vida sexual não é sinônimo de perversão ou de perda da sensibilidade sexual."11 (ARMAND, 2000, p. 55). A prática do amor livre pressupunha a educação da vontade, de maneira que a cada um possa determinar por si até que ponto poderia ir as suas próprias paixões e inclinações. "A liberdade sexual é exclusivamente de ordem individual." ${ }^{2}$ (ARMAND, 2000, p. 55). Portanto, deve haver um grande reforço na questão da educação sexual: para evitar doenças venéreas e gravidez não desejada. No período que precede a puberdade o ser humano não deveria ignorar nada do que concerne à vida sexual, pois a atração dos sexos é inelutável, seja considerada do ponto de vista sentimental, seja do emocional ou fisiológico (ARMAND, 2000). "Em outros termos, não se trata tanto da quantidade ou do número de experiências, como da qualidade do experimentador."13 (ARMAND, 2000, p. 55). Em síntese, "[...] a liberdade da vida sexual está ligada, no sentido individualista, à educação sexual preparatória e ao poder da determinação individual." "14 (ARMAND, 2000, p. 55).

A partir de vasto estudo sobre experiências comunitárias - owenistas, fourieristas, icarianas, os doukhobors, huteristas, menoitas, as colônias sionistas, la república de los niños, a Colônia Cecília, no Brasil, e várias no Estados Unidos, Armand conclui que esses agrupamentos têm maior probabilidade de duração e funcionamento quando eliminam as relações regulares entre companheiros e companheiras; se as mulheres não necessitam de proteção de um companheiro para sobreviver; se os nascimentos são limitados; e se as crianças, depois do desmame, são confiadas, ao menos durante o dia, a educadores de vocação, para não escravizarem as mães. "Todo centro da vida em comum deve ser um campo ideal de experiências para a prática de 'camaradagem amorosa', 'pluralismo amoroso', de todo sistema tendente à anulação do sofrimento sentimental." ${ }^{15}$ (ARMAND, 1934b, p. 9). Não importa se as comunidades são muito ou pouco duradouras, diz ele. $\mathrm{O}$ que importa é a experiência que aí se vive. O que importa é que, por um tempo, pessoas descontentes dentro do sistema capitalista possam viver essa experiência. O associativismo seria apenas um expediente, pois em última instância está o indivíduo e sua felicidade.

Em 1925, Émile Armand começou a organizar associações para promover seus ideais de camaradagem amorosa (camaraderie amoureuse) (Richard SONN, 2010). Casais se candidatavam para participar desses agrupamentos. Em 1927, ele anunciou que tinha 53 membros na França, Alemanha, Estados Unidos, Brasil, Suíça, Argentina e Marrocos. No ano seguinte, ele anunciou que a desproporção entre os membros do sexo masculino e feminino exigia que todos os novos candidatos do sexo masculino deveriam ser acompanhados por uma contraparte feminina (SONN, 2010). Dolors

\footnotetext{
7 "[...] la facultad de amar pluralmente, en su triple forma intelectual, sentimental y carnal."

8 "[...] la monopolización de los órganos sexuales y táctiles, de la piel y del sentimiento de un humano en beneficio de otro, exclusivamente."

9 "[...] de este terrible azote social que son los celos sexuales en la humanidad."

10 "En amor, como en todo lo demás, es la abundancia lo que aniquila los celos y la envidia. He aquí por qué la fórmula del amor en libertad, todos a todas, todas a todos, está llamada a ser la preferida del medio anarquista."

11 "[...] libertad de la vida sexual no es sinónimo de perversión o de pérdida de la sensibilidad sexual."

12 "La libertad sexual es exclusivamente de orden individual."

13 "En otros términos, no se trata tanto de la cantidad o del número de experiencias, como de la calidad del experimentador."

14 " [...] la libertad de la vida sexual queda unida, en el sentido individualista, a la educación sexual preparatoria y la potencia de determinación individual."

15 "Todo centro de vida en común debe ser un campo de experiencias ideal para la práctica de la 'camaradería amorosa', del 'pluralismo amoroso', de todo sistema tendente a la anulación del sufrimiento sentimental."
} 
Marin (2010) diz que na Espanha houve organização de comunidades amorosas anarquistas, nos anos de 1920 e 1930, com base no pluralismo sexual, e para acessá-las há que investigar na correspondência que estabeleceram com Armand, com a revista L'En-Dehors.

Do Brasil, uma carta de Giovanni Rossi, endereçada a Armand, narra um caso de amor livre na Colônia Cecília, no Paraná; Rossi descreve nuanças psicológicas que envolveram a experiência amorosa entre uma mulher e dois homens; a aceitação do fato pela comunidade; declara que a Colônia teoricamente fora pensada para o exercício do amor livre, seguindo as ideias de Armand, mas, na prática, somente esse caso vinha acontecendo (BAIGORRIA, 2006)..$^{16}$ Outra carta, dos arredores de Paris, assinada por uma una compañera del Grupo Atlantis, de 29 de junho de 1924, narra o cotidiano de amor livre praticado pelo grupo de casais, a "cinco léguas de distância de toda civilização". Sobre a misteriosa autora da carta: "Armand somente disse: 'As razões pelas quais não é possível nos expandir fazem com que este grupo, cuja atividade é clandestina, seja obrigado, para subsistir, a se manter de modo estritamente incógnito."'17 (BAIGORRIA, 2006, p. 76).

As ideias de amor livre armandista encontraram seguidores, como se disse acima, mas também adversários. Já mencionamos também que, na Espanha, uma crítica contundente veio da brasileira Maria Lacerda de Moura, acolhida nas páginas da Estudios. Lacerda juntava-se a Armand ${ }^{18} \mathrm{em}$ várias frentes de luta anarquista: individualismo, pacifismo, anticlericalismo, defesa da objeção de consciência, vegetarismo, luta contra o casamento monogâmico; defesa da educação sexual, da maternidade consciente e propaganda do neomalthusianismo. Não obstante, Lacerda combateu peremptoriamente a camaraderie amoureuse praticada pelos companheiros de L'En-Dehors. 0 "todas para todos" tem um sentido prático, diz ela (MOURA, 2005c, p. 157). O que querem esses 'comunistas do sexo' é pura precaução de viajantes para evitar lupanares e, assim, sem nenhum esforço e risco, ter as mulheres que Ihes agradam às mãos. Não Ihe agradava considerar o sentimento amoroso como qualquer outro sentimento do organismo. Não acreditava que a cooperativa amorosa colocasse fim aos sentimentos inferiores - ciúmes e dominação masculina. Para ela, todo agrupamento é um duplo crime: diminui o indivíduo e divide a humanidade. "Agrupar os homens - é sempre fazêlos inimigos de outros homens." (MOURA, 2005c, p. 173). "Que me perdoe o camarada Armand [...]"19 (MOURA, 1934a, p. 23), ela afirma que tal proposta é "[...] o retorno à promiscuidade, ao comunismo sexual degradante, no qual a mulher continua representando o papel de coisa, objeto de prazer, eleita sempre e quase nunca com direito a escolher." ${ }^{20}$ (MOURA, 1934a, p. 22).

Maria Lacerda ampara-se na filosofia da vontade de harmonia de Han Ryner e nas suas ideias de amor plural como base das relações humanas para fundamentar a lógica de seu pensamento sobre o amor, o qual não se restringe ao sexo. Em Han Ryner ela encontra o verdadeiro sentido do amor. "O Amor (grafado em maiúscula) desdobrado, largo, infinito, eterno, vindo de profundidade dolorosa, voltado para dentro do próprio ser, para poder voltar-se imediatamente para as criptas profundas ou para os abismos desconhecidos dos outros seres." (MOURA, 2005c, p. 149-150). É ○ amor amplo, às claras, sem subterfúgios, sem hipocrisia, sem mentiras convencionais, platônico ou integral, mas, o Amor sem exclusivismo sexual ou afetivo, sem ciúmes, sem paixões; simultâneo ou sucessivo, conservando sempre a deliciosa recordação da felicidade anterior (MOURA, 2005c).

\section{O pluralismo amoroso}

O amor é uma escolha não deliberada; é uma predileção impulsiva de nossas forças internas, abaladas por algo misterioso; é a liberdade absoluta de escolher espontaneamente poderíamos dizer, inconscientemente - mas nunca a promiscuidade ou a servidão galinácea. ${ }^{21}$ (MOURA, 1934a, p. 23).

Para Maria Lacerda, a verdadeira liberdade amorosa é a defendida pelo neo-estoico Han Ryner que, em sua novela L'amour plural, Orfeu é o eleito e aceita o amor sincero de qualquer mulher, sempre que a nova experiência não desfaça a riqueza das anteriores (MOURA, 2005c).

O Amor deve ser recebido sempre como uma benção de luz.

Quem quer que seja que marche para o meu Amor, por esse fato somente, torna-se para mim um Deus.

\footnotetext{
${ }^{16}$ Ver também Rossi (2005).

17 "Armand sólo dice: 'Razones sobre las que no nos es dable extendernos hacen que esta agrupación, cuya actividad es clandestina, esté obligada para subsistir a mantener el más estricto incógnito."'

${ }_{18}$ Conforme Miriam L. M. Leite (2005, p. 20-21). Armand conheceu a colônia anarquista de Guararema. Há uma carta de Maria Lacerda a Armand, datada de 1932, expedida de Guararema, pedindo que não interrompesse o envio da revista L'En-Dehors, pela falta de pagamento e pelas dificuldades com o governo de Getúlio Vargas.

19 "Que me perdone el camarada Armand [...]."

20 " "....] el regreso a la promiscuidad, al comunismo sexual degradante, en el que la mujer sigue desempeñando el papel de cosa, objeto de placer, elegida siempre y casi nunca con derecho a elegir."

21 "El amor es una elección no deliberada; es una como predilección impulsiva de nuestras fuerzas internas, sacudidas por un algo misterioso; es la libertad absoluta de escoger espontáneamente - y podríamos decir que inconscientemente -, pero nunca la promiscuidad ni el servilismo gallináceos."
} 
Saber amar é dar-se inteiramente.

Nosso amor é muito grande para conhecer o ciúme.

Toda alma é andrógina e pode amar à direita como à esquerda. (MOURA, 2005c, p. 146).

Muitos dos princípios do anarquismo ryneriano coincidem com os de Armand: o indivíduo deve ser um crítico constante da sociedade e converter-se na demonstração prática de que é possível viver a utopia no nível pessoal. Nesse sentido, a ideia de liberdade está associada a uma vida simples e natural, com o mínimo de laços possíveis, menosprezando a ideia de possessão, inclusive a amorosa. Ryner defendeu também uma 'fraternidade de amor' em que a procriação não prejudicaria a sexualidade livre, mas não concordou com Armand quanto à camaraderie amoureuse, por considerar que em toda organização há alguma forma de centralismo. Suas novelas pareciam estar satirizando as ideias de Fourier, e de Armand. Ryner também tinha ressalvas em relação ao individualismo de Stirner, tão apregoado por Armand.

O mundo ideal, para Ryner, deveria ser construído pela mudança interior na busca de uma vida harmônica e equilibrada. Ele concebeu dois tipos de individualismo: a) da vontade de vida; b) da vontade de humanidade. No primeiro, encontra-se a fórmula de Nietzsche: "O individualista da vontade de dominação [...]. O nietzschienismo não me satisfaz [...]". ${ }^{22}$ (RYNER, 1922, p. 21). Trata-se de um individualismo egoísta. ${ }^{23}$ No segundo tipo, há os verdadeiros individualistas: Sócrates, Epicuro, Jesus e Epíteto. Sócrates ensinou a procurar no próprio interior a sua verdade; em Epicuro, encontramos temperança e doutrina da vontade; Epíteto, no seu estoicismo, foi feliz nas situações mais dolorosas, suportou corajosamente a pobreza e a servidão; o fraterno Jesus, tendo vivido livre e errante, alheio a todo vínculo social, foi inimigo dos sacerdotes, dos cultos exteriores e, em geral, de toda organização.

Com esses clássicos, que Ryner conhecia de primeira mão, segundo seus biógrafos, o filósofo da "sabedoria risonha" (RYNER, 1928), pregou a virtude desinteressada para criar a felicidade, um estado de espírito livre de todas as servidões; propôs um individualismo ético e moral, que começa com a fórmula de Sócrates: "conhece-te a ti mesmo" (RYNER, 1921, p. 16), o que inclui a dupla crítica: "da minha vontade e do meu poder" (RYNER, 1921, p. 18). "Entendo por individualismo a doutrina moral que, não se apoiando em nenhuma tradição, em nenhuma vontade exterior, não se dirige senão à consciência individual." (RYNER, 2012b, p. 21).

A descoberta de Han Ryner, por Maria Lacerda, funcionou como um elo e um apoio de coesão entre sua prática educacional, de cunho político, e suas aspirações místicas de autoconhecimento (LEITE, 1984). Numa pequena Autobiografia, de 1929, publicada no jornal O Combate (LEITE, 2005), Maria Lacerda conta que depois de se ter desiludido com o catolicismo, já lá na infância, e depois com o espiritismo praticado pelo pai; depois de ter se ausentado da Sociedade Teosófica e da Maçonaria; depois que se afastara de tudo quanto precisasse de ritual e espírito religioso, das associações feministas, e também masculinas; depois de perder todas as ilusões e esperanças; recebera, da França, obras de Han Ryner e, com este, diz ela, "[...] veio a solução desejada [... ] é o individualismo neo-estoico de Han Ryner que me iluminou a consciência e me deu a noção mais alta da liberdade ética. Fraternismo e subjetivismo, amor e sabedoria. Jesus e Epíteto." (MOURA, 2005b, p. 43).

A identificação que Lacerda estabeleceu com Han Ryner foi tão grande, segundo Leite (2005), que, apesar de ter sempre sustentado que pensava por si mesma e que não queria fazer parte de partidos e seitas, escreveu o livro Han Ryner e o amor plural, cujo esboço apresentou preliminarmente ao homenageado. Ela se tornou conhecida, na historiografia internacional anarquista, como a discípula de Han Ryner e divulgadora de sua obra na língua portuguesa. Quando morreu, em 1945, deixou duas obras dele traduzidas (Os pacíficos e O quinto evangelho), cujos originais se perderam sem ser publicados (NEVES, [1961]). Para ela, Han Ryner é o Sócrates moderno, "[...] de caráter estoico e capaz de despertar em nós um esforço sobre-humano para avançar em direção a uma realização interior cada vez mais bela e, acima de tudo, mais profunda." 24 (MOURA, 1936, p. 31-32).

Han Ryner, embora hoje pouco conhecido, à época, sua obra - novelas e obras filosóficas foram traduzidas em vários idiomas - despertara grande interesse nos meios anarquistas. Seu reconhecimento esteve também associado a uma certa aura de figura respeitada por sua solidez ética, modéstia e austeridade em sua vida pessoal, e por sua independência intelectual, assim como por uma concepção filosófica mais intimista, mais subjetivista, com uma maior capacidade de conexão com a sensibilidade de muitos libertários (DIEZ, 2007). Em dois de seus romances Le crime d'obéir (1900) e Le sphinxrouge (1905), Han Ryner criou o tipo de herói individualista refratário à ordem social que se insurge contra o meio para viver de acordo com sua consciência,

22 "L' individualiste de la volunté de puissance [...]. Le nietzscheinisme ne me satisfait pas [...]."

${ }^{23}$ Embora Ryner tenha seguido o pensamento nietzschiano para formular muitos aspectos de seu individualismo, discordava da doutrina da 'vontade de poder'.

24 "[...] de un carácter estoico y capaz de despertar en nosotros un esfuerzo sobrehumano con objeto de dirigirnos hacia una realización interior cada vez más bella, y, sobre todo, más profunda." 
custe o que custar. Depois, num terceiro romance, Los pacifiques (1914), a objeção de consciência é ampliada como ética de toda a sociedade. Los pacifiques descreve uma utopia vivida por uma comunidade anárquica, na submersa ilha Atlântida, um povo que vive nu, sem governo e sem disciplina imposta, sem hierarquia, que se nega a usar a força sob qualquer pretexto, que vive em harmonia com os animais e que é evidentemente vegetariano. "Não comande jamais e não obedeça jamais. Não trabalhe para aquele que não faz nada." ${ }^{25}$ (RYNER, 1914, p. 150).

Na década de 1920, aparece na obra de Han Ryner a questão do amor. Em 1924, publica Le drame d'êtredeux (RYNER; Aurelie AUREL, 1924), novela epistolar entre ele e Mme. Aurel, na qual um homem e uma mulher discutem o amor e a relação entre os dois sexos, refletindo sobre compreensão mútua e o respeito à individualidade. Depois, explorando o território do amor plural, o problema do ciúme, do exclusivismo e das mentiras em matéria de amor único ou plural organizado, lança a trilogia L'amour plural (1927), Prenez-moi tous! (1930) e Les orgies sur la montagne (1935). As personagens principais são Orfeu (antonomásia de Ryner) e Eurídice, com referências explícitas à mitologia grega. As histórias narradas levam as personagens a um processo de autoconhecimento. Como qualquer resposta é individual, só o segredo de cada indivíduo pode dizer o que é a verdade de cada um. Ryner, a sua maneira, simbólica, irônica e zombeteira, à moda dos cínicos antigos, desenvolve sua crítica à ideia armandista de 'amor livre organizado', argumentando na direção de um amor plural, subjetivo, comandado apenas pela vontade interior.

Na primeira novela, L'amour plural, Orfeu aceita o amor de diversas mulheres, cada qual com temperamento próprio. "Um amor não deve jamais excluir um outro amor. Quem exclui o amor não será chamado de amor."26 (RYNER, 1927, p. 197). Eurídice, a esposa; Marie Louise, a pluralista; a alegre e fervorosa Denise; Aloysia, pedante insuportável, protótipo de mulher intelectual; Irene, a pobre e doce musa, um tanto louca; Miranda, a teosofista, figura alucinante. Orfeu amou verdadeiramente e sem mentiras a todas, cada qual aportando ao amado uma experiência amorosa singular. "Sou fiel, mais fiel que você, sou fiel à natureza."27 (RYNER, 1927, p. 191). Há passagens sobre androginia. A heroína de L'amour plural, Marie-Louise (a síntese da tese ryneriana), ama o marido, ama outros dois camaradas e também Orfeu. Leitora de Emmanuel Swedenborg declara que é capaz de amar mulheres, "[...] pois somos andróginas". ${ }^{28}$ (RYNER, 1927, p. 189). Miranda, por sua vez, diz a Orfeu: "Você é uma das duas asas que transportam para o mundo superior o andrógino, onde iremos nos fundir [...]"29 (RYNER, 1927, p. 146). E Denise, na sua insistência em se aproximar de Orfeu, declara: "Nossa reaproximação constituirá o maravilhoso andrógino primordial e definitivo [...] somente os andróginos poderão se casar, e nosso beijo nos levará ao voo soberano." ${ }^{30}$ (RYNER, 1927, p. 141-142). ${ }^{31}$ A história dessas figuras continua em Prenez-moi tous! (1930). Aqui, Han Ryner é enfático na crítica, produzindo uma espécie de paródia da camaraderie amoureuse armandista, para, daí, aprofudar sua concepção de pluralismo amorososo. Acrescenta uma personagem nova, a de Kersos, que se envolve numa relação homoafetiva com Orfeu. O grupo de mulheres, amantes de Orfeu, em Prenez-moi tous (espécie de mênadas ou bacantes que amam o seu Dionisio/Orfeu) tomam a inciciativa da criação de uma irmandade do amor (Frère d'amour), com argumentos tirados dos periódicos franceses L'En-Dehors de E. Armand (RYNER, 1930). No cotidiano da Frére, cada integrante do grupo enfrenta seu processo de autoconhecimento, numa espécie de descida ao inferno. Mentiras, traições, exclusivismos, ciúmes e até o assassinato de Miranda que amava Orfeu, amante de Denise e contejado por Kersos, o rapaz homossexual que se submetera às regras da troca de casais heterossexuais.

Em 1935, aparece Les orgies sur la montagne. O romance tem início com um episódio da mitologia grega. Orfeu desce ao inferno para encontrar sua esposa Eurídice, morta por uma cobra. Ao trazê-la de volta ao mundo dos vivos, ele comete um erro e a perde para sempre. É grande o sofrimento de Orfeu pela perda da mulher amada. Em sua deambulação, Orfeu é levado a procurar Eros. A partir desse momento, Han Ryner passa a evocar os amores de Orfeu, múltiplos, bissexuais, homossexuais, figuras viris, femininas, andróginas, ninfetas. Cada momento de entrega dos corpos às carícias é descrito com beleza sensual, respeito e apreço pela singularidade dos parceiros, envolvidos em dubiedades e sutilezas, fugidias e transitórias enquanto gênero. "Orfeu desprezava o amor único, o canto monótono e regrado; ele reverenciava as orgias, a paixão e a música vibrante." ${ }^{2}$

\footnotetext{
25 "Ne commandez jamais et n'obéissez jamais. Ne travaillez point pour celui qui ne fait rien. "

26 "Un amour ne doit jamais exclure un outro amour. Ce qui exclut l'amour ne saurait s'appeler amour."

27 "Je suis fidèle, plus fidèle que toi, je suís fidèle à la nature."

28 "[...] on est androgyne."

29 "Tu es une des deu ailes que porteront au monde supérieur l'androgyne où nous nous fondrons [...]."

30 "Notre rapprochement constituera le merveilleux androgyne primordial et définitif [...] seulement l'androgyne purra s'épouser et notre baiser monter d'un vol souverain."

${ }^{31}$ As doutrinas de Swedenborg, místico do século XVIII, como sabemos, ensinava que o andrógino, semelhante aos anjos, fora no começo e será de novo no fim dos tempos. Na França, Balzac escreve Serafita (1835), romance que homenageia e ilustra as doutrinas de Swedenborg sobre o andrógino, um ser perfeito, mais espiritual que carnal, imensamente erudito, dotado de faculdades mentais acima dos comuns mortais.

32 "Il méprisait l'amour unique ou le chant monotone et réglé; il révait des orgies, de la passion et des musiques éclatantes."
} 
(RYNER, 1935, p. 41). A desenvoltura erótica da escrita das histórias de amores plurais deve ter chocado a puritanos à época, mas a beleza da poesia que aparece nos contextos amorosos talvez tenha desagradado também aos adeptos de encontros casuais e puramente carnais.

Maria Lacerda de Moura, como já se disse acima, defendeu e divulgou a obra de Ryner. Na Estudios, ela dedicou dois artigos ao mestre. No Brasil, publicou Han Ryner e o amor plural (1933), transcrevendo e comentando, sem objeção, passagens das novelas l'amour plural, Le drame d'être deux, Prenez-moi tous!, La sagesse qui rit e de outras duas novelas do filósofo ensaísta francês, sobre as quais não tratei aqui - Parabole cyniques e Voyages de Psycodore. Tudo indica que ela não conheceu Les orgie sur la montagne. Ao menos, não detectei em sua obra referência a esse livro de Ryner.

\section{Amor livre, Amor hétero}

Bacante, aprenda a descobrir em todos os lugares, a despertar, a criar, se necessário, o Eros feminino. Bacante, aprenda a encontrar, a despertar, a criar em toda parte o Eros masculino. ${ }^{33}$ (RYNER, 1935, p. 80).

Em Les orgies sur la montagne, Ryner discorre sobre Dionísio, celebrado pela sua forma andrógina, e mais ainda pelo seu dimorfismo, pelo seu poder alternativo, alegre e triste, novo e velho; é deus e é deusa. "Acolhedor de todas as alegrias, acessível às volúpias diversas, doador e doadora de todos os prazeres. Divindade duplamente satisfatória para os dois sexos, envia-me um amor que se pareça com o seu amor." ${ }^{34}$ (RYNER, 1935, p. 85). A voz que acompanha a lira de Orfeu, não se sabe se é de um homem ou de uma mulher. O hino celebra Bacos, em honra a Dionísio (RYNER, 1935). Não a Apolo, pois este é um inimigo da alegria (RYNER, 1935). Orfeu sobe à colina. Bacantes com vestes rituais dirigem-se para Phallus, símbolo da fecundidade e da alegria. Rodeiam Dionísio. Amam Orfeu. Carícias inomináveis. Embriaguez. A festa ritual é como as estações do ano. Vão e vêm. Orfeu encontra Androdore, efebo belo e forte como um homem, gracioso e flexível como uma mulher ou uma criança. Se Orfeu desejar, poderá esposá-la. E como homem poderá ser seu amante (RYNER, 1935).

Poderíamos afirmar que são só fantasias mitológicas, e concordar com a personagem pluralista Marie-Louise da novela L'amour plural. Han Ryner não pratica o que prega, o que tudo indica que era verdade na vida real. Nas últimas páginas dessa novela, as personagens reunidas debatem o assunto do amor. Na ficção, Ryner e Armand estão presentes. Marie-Louise declara ser mais favorável a Ryner do que a Armand. Ela argumenta que os anarquistas libertários acreditam acima de tudo na liberdade, razão pela qual condenam as constrições do casamento, mas o agrupamento armandista é uma maneira de esposar todo o grupo. É a morte do amor plural (RYNER, 1927). Maria Lacerda cita essa passagem para criticar a camaraderie amoureuse armandista. "Talvez Marie-Louise tenha razão [...]" - diz Lacerda. "Suspeito, por vezes, que no seu amor plural (de Armand) e dos companheiros de L'En-Dehors haja uma simples precaução de viajante que não gosta de lupanar." (MOURA, 2005c, p. 157). Contudo, Marie-Louise objeta também a Ryner por não praticar o que prega (RYNER, 1927), o que talvez para o temperamento de Maria Lacerda isso fosse uma virtude.

Em outro momento, Maria Lacerda comenta o amor de Orfeu e Kersos, considerando que nessas páginas Ryner "discorre em torno do masoquismo e do sadismo", e resume: "[...] todo o ódio, toda a perversidade ou, toda a indiferença com que pode agir um apaixonado para chegar ao seu objetivo, e o despertar de instintos ao calor da tal organização amorosa." E acrescenta: "Belas páginas de psicanálise Han Ryner estuda em Kersos e na psicologia homossexual." (MOURA, 2005c, p. 176)..$^{35}$ Afinal, diz Lacerda, é Orfeu quem se oferece a Kersos. "Esse estudo confirma a análise científica de Marañon: 'Todas as criaturas têm, dentro de si, os dois sexos, em lutas para o predomínio do mais forte; é o atavismo hermafrodita'." (MOURA, 2005c, p. 177).

Essa é uma conclusão de Maria Lacerda. Até onde foi minha leitura, não percebi que Ryner tivesse feito uso das teorias que psicologizaram o sexo e transformaram o hermafroditismo em degeneração humana. O pensamento hyneriano é fortemente inspirado na antiguidade clássica, tecendo interpretações próprias de diversos filósofos (sofistas, cínicos, estoicos). No meu entendimento, com base na triologia que vimos acima, L'amour plural (1927), Prenez-moi tous! (1930), Les orgies sur la montagne (1935), Ryner como filósofo neo-estoico, individualista subjetivista, desenvolve sua ideia de amor plural como base para as relações humanas. Os protagonistas de suas novelas tratam de demonstrar que os indivíduos, nas suas evoluções pessoais em busca da

\footnotetext{
33 "Bacchante, apprends à découvrir partout, à éveiller, à créer, s'il le faut, l'Eros féminin. Bachante, apprends à dénicher, à éveiller, à créer partout l'Eros masculin."

34 "Accueillant à toutes les joies, acessible aux voluptés diverses, donate et donatrice de tous les plaisirs. Divinité doublement hereuse par tes dous sexes, envoie-moi un amour semblable à ton amour."

${ }^{35}$ Difere do andrógino, mais ligado à perfeição e completude, o hermafrodita, mais ligado à degeneração sexual e à homossexualidade, visto como uma figura diminuída no seu Ser. Para uma genealogia do hermafroditismo, ver Fransisco García (1999).
} 
harmonia interior, podem deixar para trás a velha sociedade. Ele configura, na prática da pluralidade amorosa das suas personagens, uma representação simbólica do exercício cotidiano da liberdade individual e subjetiva.

Prenez-moi tous! é uma paródia da camaraderie amoureuse armandista, como já se disse acima, e para a composição literária que ri do agrupamento de casais heteros, a introdução do caso do amor homossexual funciona para rebater a organização do amor. O amor não tem limite. "Organizar a liberdade, é criar a escravidão [...]"36 (RYNER, 1930, p. 247) é a frase que antecede a cena do encontro homoafetivo. Nesse dia, Orfeu encontrava-se fechado, em estado de dúvidas. À hora Coronal, momento em que os casais se formam para a noite de amor, Orfeu é sorteado para eleger sua parceira. Ele atravessa a sala e se dirige à Kersos. As palavras rituais são pronunciadas: "- Amante Kersos, com alegria dou-lhe meu amor. - Amante Orfeu, meu coração e meu corpo dão boas-vindas com alegria ao seu amor." ${ }^{37}$ (RYNER, 1930, p. 251). Todos os irmãos e irmãs olham, comovidos e encantados, o rosto extático de Kersos, enquanto seus lábios tocam os lábios de Orfeu. Os dois homens, abraçados pela cintura, retiram-se iluminados e harmosiosos. Somente Denise, a Grande Amante, franse as sobrancelhas. Ela contempla com tédio o novo casal e suspira interiormente: "Ce muffle d'Orphée m'arrache mon meilleur instrument." (RYNER, 1930, p. 252). Numa tradução livre, ela teria dito: Esse imbecil do Orfeu me arranca meu melhor instrumento (neologismo de homem).

A obra de Ryner, escrita em forma de parábolas, contos e novelas, num estilo que se pode considerar simbolista, fortemente sugestivo, mescla histórias reais e ficcionais, numa textura onírica que amplia significativamente as possibilidades de leitura. O autor libera o pensamento filosófico de acordo com a beleza literária e, no seu gênero, há uma espécie de riso rabelesiano, indiferente a tudo o que não lhe parece essencial, própria de uma sabedoria ou do sábio (palavras constantes em sua obra), produzindo uma espécie de arte de viver.

Mas, que não se pense que são apenas divagações literárias. Han Ryner dedica um ensaio para tratar do assunto do sexo e do amor, na vida real e contemporânea. Para ele, apenas o ser humano ama a qualquer época do ano; o único a conhecer "[...] os deliciosos langores que sucedem o ato sexual. [...] Seu corpo é sensível por toda a superfície [...]" (RYNER, 2012a, p. 36), fenômeno que produz "[...] um mundo muito mais variado do que se pensa [...]" (RYNER, 2012a, p. 34). E, ainda de acordo com o autor, se na "definição estreita [...] o amor é a atração de um sexo pelo outro [...] quer o fato agrade, quer não, existiram e continuam existindo amores entre pessoas do mesmo sexo." (RYNER, 2012a, p. 31). E lamenta o crime cometido a Oscar Wilde, pelos juízes ingleses. Várias legislações condenam o amor homossexual, diz Ryner, que é recebido com zombaria ou severidade pela opinião pública. E pergunta:

Será que isso acontece por que essa forma de amor seguramente evita as armadilhas do gênio da espécie? Ou seria ele condenado pelas mesmas razões que condenam o malthusianismo (qualquer legislador é, por procuração, um grande repovoador)? Ou ainda por que as religiões modernas condenam o prazer, só lhe concedendo alguma tolerância caso ele contribua às supostas finalidades de Deus ou da Natureza? (RYNER, 2012a, p. 32).

Nesse sentido, percebemos que Maria Lacerda aproxima-se mais de Armand, do que de seu mestre Han Ryner. Ambos, Armand e Lacerda, não contemplaram em seus discursos a questão da homossexualidade. Ele, que propagou o 'sexo sem travas' e considerou o amor 'acima do bem e do mal', preocupou-se apenas com as relações heterossexuais. Ela, que mais defendeu o amor livre em termos feministas, mirou o casamento indissolúvel e monogâmico. "A união monogâmica e a família indestrutível são a base e o apoio da religião, do Estado e da propriedade privada." ${ }^{38}$ (MOURA, 1933, p. 15). Para Lacerda, o casamento era a causa, não só da escravidão da mulher, mas também da prostituição, da exigência descabida da virgindade, do preconceito contra as 'solteironas' e da desqualificação da mulher intelectual.

O indivíduo que impõe às mulheres um amor único, uniforme, para toda a vida, que monopoliza, que subjuga e constrange as expansões sexuais femininas, constitui um inimigo inconsciente da emancipação humana e um obstáculo ao progresso ético da humanidade. ${ }^{39}$ (MOURA, 1933, p. 17).

Armand, por sua vez, defende o amor livre a partir da suposição, para ele óbvia, de que as funções dos sexos são determinadas pela natureza. "As coisas são determinadas de tal maneira que a raça humana é composta por seres de diferentes sexos cuja aproximação é indispensável

36 "Organizer la liberté, c"est créer la servitude."

37 "- Amant Kersos, je donne joyeusement mon amour. - Amant Orphée, mon coeur et mon corps accuillent joyeusement ton amour."

38 "[...] la unión monógama y la familia indestructible son la base y sostén de la religión, del Estado, y de la propiedad privada."

39 "El individuo que impone a la mujer un amor único, uniforme, para toda la vida, que monopoliza, que sojuzga y coacciona las expansiones sexuales femeninas constituye un enemigo inconsciente de la emancipación humana y un obstáculo para el progreso ético de la humanidad." 
para perpetuar a raça." 40 (ARMAND, 2000, p. 52). E o fato de que a procriação possa ser voluntária em nada suprime a atração sexual. "Os sexos se atraem naturalmente, se procuram normalmente: esse é o fato original, primordial, a base fundamental das relações entre as duas metades do gênero humano." ${ }^{41}$ (ARMAND, 2000, p. 52). O amor é "[...] a atração ou a paixão sexual, seja o desejo e a satisfação do apetite sexual, satisfação manifestada pelo coito ou realizada pela necessidade de tocar, acariciar, beijar alguém do sexo oposto e até desfrutar de sua presença, entreter-se com ele." (ARMAND, 2012, p. 21, grifo meu).

"O que acontece é que o ambiente humano aguenta com muito trabalho a sujeição monogâmica ou monárquica, e essa forma de união sexual é apenas externa. Essa é a verdade." ${ }^{2}$ (ARMAND, 2000, p. 64-65). Ainda de acordo com o autor, a história nos mostra que os povos não monogâmicos não cederam naturalmente a passagem para o monogâmico; os gregos eram dissolutos, incestuosos, homossexuais (única vez que vi referência à homossexualidade, na obra de Armand), e produziram obras artísticas e filosóficas para a humanidade. "Comparem a produção arquitetônica e científica dos árabes polígamos com a ignorância e grosseria dos cristãos monogâmicos da mesma época." ${ }^{43}$ Para Armand, nada nos faz presumir que a monogamia ou a monandria sejam naturais. "Pelo contrário, são artificiais." 44 (ARMAND, 2000, p. 68). Os povos só teriam se sujeitado à monogamia sob a lei e a polícia.

Na antologia Anarquismo y homosexualidad, Cleminson (1995) reúne diversos artigos dedicados à homossexualidade, publicados em quatro revistas (Generación Consciente, Estudios, Revista Blanca e Iniciales), entre 1924 e 1935, mostrando as contradições que alguns médicos anarquistas espanhóis viam entre o amor livre e as práticas homossexuais, chegando a tolerar a homossexualidade congênita, mas não aquelas que procurassem simplesmente por novas sensações. Estas eram vistas como práticas perversas (CLEMINSON, 1995). De modo geral, era preciso entender as razões pelas quais saem indivíduos homossexuais ou com práticas homossexuais, para tentar a cura e para sanar as causas ambientais, evitando que a prática florescesse.

\section{Libertária e feminista}

Considero que o anarquista feminofóbico, aquele que não se importa em obter o concurso da mulher ou aquele que não dá importância à sua ação, é, não apenas um equivocado, mas também um inimigo inconsciente da emancipação humana. ${ }^{45}$ (MOURA, 1933, p. 16).

O sociólogo espanhol Santiago Valentí Camp (1875-1934), ativista político e feminista, ao produzir um extenso levantamento das feministas que atuavam em diversos países da Europa e da América, diz que no Brasil encontrou apenas o nome de Maria Lacerda de Moura como figura conhecida internacionalmente. E mais. Mesmo nos países em que a literatura feminista alcançou maior esplendor, não abundavam escritoras com o temperamento da brasileira Lacerda. "Sem dúvida, a produção filosófica e pedagógica devido à grande ideóloga, tem um valor intelectual extraordinário, mas, do ponto de vista ético, talvez sua personalidade se destaque superlativamente." ${ }^{46}$ (VALENTí CAMP, 1931, p. 11). Valentí Camp sugere chamar Lacerda de Elena Key brasileña. Como a grande inovadora sueca, "Maria Lacerda expressa suas ideias com toda emotividade, sem rodeios, e com inusitada e assombrosa valentia. Que bravura e sensatez revela quando, ocupando-se da independência feminina, exclama: 'O espírito não tem sexo!'." ${ }^{47}$ (VALENTí CAMP, 1927, p. 349).

De fato, Maria Lacerda de Moura foi quem mais se destacou na defesa do amor livre em conotações feministas. Afirmava que a camaradería amoureuse armandista, nessa 'reciprocidade' obrigatória, sob o pretexto de um princípio de liberdade, a mulher sairia prejudicada e a dominação masculina não cessaria. Ela também denunciava tanto os reacionários quanto os revolucionários contrários ao neomalthusianismo. Para eles, não existe o problema feminino. A mulher para eles está a serviço da procriação irrefletida e inconsciente. Veem a mulher como uma máquina destinada

40 "Las cosas están determinadas de tal modo que el género humano se halla compuesto de seres de sexos diferentes cuya aproximación es indispensable para perpetuar la raza."

41 "Los sexos se atraen mutuamente, se buscan naturalmente, normalmente: este es el hecho original, primordial, la base fundamental de las relaciones entre las dos mitades del género humano."

42 "Lo que pasa es que el ambiente humano aguanta con mucho trabajo la sujeción monogámica o monándrica, y esa forma de unión sexual no es más que exterior. Esa es la verdad."

43 "Comparen la producción arquitectónica y científica de los árabes polígamos con la ignorancia y la tosquedad de los cristianos monógamos de la misma época."

44 "Por el contrario, son artificiales."

45 "Yo considero que el anarquista feminófobo, el que non se preocupa por obtener el concurso de la mujer o aquel que no concede importancia a su acción, es, no solamente un equivocado, sino también un enemigo inconsciente de la emancipación humana."

46 "Es indudable que la producción filosófica y pedagógica debida a la gran ideóloga, tiene un extraordinario valor intelectual, pero desde el punto de vista ético, acaso su personalidad se destaque de modo superlativo."

47 "Maria Lacerda expresa tus ideas con toda emotividad, sin rodeos, y con inusitada y asombrosa valentía. iQue bravura y sensatez revela, cuando ocupándose de la independencia femenina exclama: 'El espíritu no tiene sexo!'." 
a fabricar carne para os canhões ou para as barricadas. Não era por animosidade aos anarquistas, diz ela, mas percebe que existe um bom número deles que, "[...] com relação à escravidão sexual e amorosa da mulher, estão ainda em mantilhas." ${ }^{88}$ (MOURA, 1933, p. 15). Estes pensam, acrescenta Lacerda, que a mulher não é nem deve ser dona de seu corpo, e sim que deve sujeitar-se aos caprichos dos homens e pertencer exclusivamente a eles; não incluem as mulheres nas lutas libertárias ou as veem como objeto sexual para seus prazeres ou procriadora para gerar seus filhos (MOURA, 1933).

E como feminista libertária, Maria Lacerda não poupou, igualmente, o feminismo de sua época. Ela tratou de assuntos que não eram ventilados pelas companheiras feministas (controle da natalidade, divórcio, virgindade, desenvolvimento intelectual da mulher) e, por isso, as considerou propagadoras de um feminismo pequeno-burguês. "Não pertenço a nenhuma associação de mulheres 'Pro Voto' nem sou do partido militarizado e militante do feminismo bélico. Tenho igualmente repugnância pelo exército catequético de certas damas de Estropajosa". ${ }^{49}$ (MOURA, 1931a, p. 19).

Maria Lacerda se tornou conhecida no exterior, especialmente com a publicação, em 1926, de Religião do amor e da beleza. Segundo ela, esse livro "[...] trouxe, além da exaltação dos adversários, outros amigos e outros sonhos"; entre a correspondência, havia uma carta "admirável do anarquista francês A. Néblind" (mentor da colônia de Guararema) que, "[...] mais do que ninguém vira a amargura" na escrita de Religiáo do amor e da beleza, e esse reconhecimento foi como um "raio macio de luz para aquecer o meu desespero". (MOURA, 2005b, p. 42). Nesse mesmo livro, Maria Lacerda de Moura pautava sua concepção de feminismo a partir do que ela chamava de "maternidade espiritual", uma concepção que defendia o amor à humanidade, veiculada pelos filhos, os "poetas anunciadores" de um novo mundo. O "amor sensual", construído em cima de sonhos de beleza, mata o ideal e envelhece; o verdadeiro amor era o "amor das almas, sempre jovem e imortal". A missão da mulher "consiste em inspirar pelo espírito e não pela carne"; "consiste em ensinar o homem a amá-la no que ela tem de mais puro e digno". (MOURA, 1926, p. 59). A "superioridade moral" da mulher viria quando estivesse à "altura de divinizar a carne [...] ligada, de fato, à espécie, pela multiplicação selecionada [...] pela eugenia, contra todas as degenerescências, contra os vícios do corpo e do egoísmo". (MOURA, 1926, p. 126).

Quando em 1932 aparece Amai e não vos multipliqueis, já depois de seu convívio com os libertários, percebe-se que o foco na "maternidade espiritual" desloca-se para o da "maternidade consciente". Lacerda aprofunda a defesa do controle da natalidade, com base na lei da população de Malthus, e reforça a tese de que o sexo é o problema humano, sob o aspecto social (MOURA, 1932). "A pobreza é questão sexual." (p. 129). "A solução da questão social está no Amor e na Maternidade Consciente." (p. 128). Maria Lacerda, antifascista e pacifista inveterada, considerava que a política de expansão demográfica desejada pelos Estados fascistas, tinha a ver com o desejo de engrossar os exércitos. "A repressão às ideias neomalthusianas resume-se no seguinte postulado burguês-capitalista-religioso: 'a pátria precisa de soldados, a usina tem necessidade de trabalhadores; a igreja tem necessidade de fiéis'." (p. 122). Miriam Moreira Leite (1984) percebe que, a partir de 1928, da esfera da defesa da mulher e da criança, submetidas ao jogo tirânico dentro da família e da escola, Lacerda passou à esfera da defesa da mulher como indivíduo diante do Estado e da Igreja.

Porém, se ela abandona a divinização da carne e adere à ciência, à crítica política e à teoria da população, para defender a autonomia da mulher, parece-nos que não abandona totalmente uma visão essencialista em que concebe o amor feminino mais sentimentalista que sexual. Ao argumentar contra o "comunismo sexual armandista", Lacerda acaba por reputar à mulher o papel passivo, o papel do "outro" do desejo. A mulher é a "presa" do homem, a sujeitada, e nunca o "sujeito" na conquista amorosa. Para Lacerda, "[...] os companheiros de L'En-Dehors introduzem [a mulher] na camaradería amorosa, como instrumento sexual [...]" (MOURA, 1931a, p. 20), o que por certo não deixa de ser verdade, considerando-se a cultura falocêntrica predominante à época e ainda vigente nos dias atuais.

A palavra prazer, cara a Armand na defesa do "sexo sem travas", é rara na obra de Maria Lacerda. Quando a menciona, reporta-se ao prazer do homem que usufrui da mulher como objeto do desejo masculino. Na "promiscuidade organizada" armandista (MOURA, 2005c, p. 165), as "carícias automáticas" serviriam para "[...] despertar em nós apenas o erotismo, os instintos puramente animais que devem ser regrados pela razão." (MOURA, 2005c, p. 159). Para defender a igualdade entre homens e mulheres, e reivindicar seu direito nas lutas revolucionárias, ela afirma: "O espírito não tem sexo."50 (VALENTÍ CAMP, 1927, p. 349). "A alma é andrógina." (MOURA,

\footnotetext{
48 "[...] con relación a la esclavitud sexual y amorosa de la mujer, están todavía en mantillas."

49 "No pertenezco a ninguna asociación femenina 'Pro Voto' ni soy del partido militarizado y militante del feminismo bélico. Me repugna igualmente el ejército catequístico de ciertas damas de Estropajosa."

50 "El espíritu no tiene sexo."
} 
2005c, p. 146). "O Universo é bissexual”. (p. 179). "Na matéria está a sexualidade animal [...]" (p. 164). Não é o corpo feminino dotado de desejos e prazeres sexuais que pauta a sua defesa da igualdade entre os gêneros.

Consideremos, no entanto, que, como vimos acima, para Maria Lacerda o sexo é a causa da miséria humana, a causa dos problemas sociais e da dominação masculina. Portanto, há algo a mais a ser observado na prédica feminista de Lacerda. A dominação sexual da mulher era a razão da sua inferioridade cultural: criada para ser esposa ou mãe, ignorante e submissa, sensível e amorosa. A defesa do amor livre pela via da crítica ao casamento foi a bandeira para uma causa feminista que tem como premissa livrar-se do sexo, mas a razão está fora do sexo. 0 casamento e o exclusivismo sexual seriam uma espécie, digamos, de cláusula de barreira que impediria a emancipação intelectual da mulher. Esta seria a sua verdadeira liberdade. Para Lacerda, os companheiros de l'En-Dehors não entendem qual é a verdadeira reivindicação feminina: "[...] o direito de ser dona de seu próprio corpo, de sua vontade, de seus desejos e de sua expansão mental, para viver a vida em toda a plenitude de suas possibilidades latentes." ${ }^{1}$ (MOURA, 1931a, p. 20, grifo meu).

Para Maria Lacerda, com base em estudos de psicologia, existem dois tipos de mulher: a mãe e a hetera, que podem se confundir na mesma pessoa. Em algum grau, trazemos um pouco mais ou um pouco menos de cada uma delas. A mulher procriadora, que vive quase instintivamente no apego aos filhos, é a do tipo mãe. Do tipo hetero, há as esposas, que se sacrificam pelo marido - tipo Penélope -, e as amantes. Mas essas diferenças não importam. O que vale é a virtude, a honestidade e a superioridade mental (MOURA, 1926). "As heteras do tipo Laïs, Phrynea, Thaïs, Sapho, Aspasia não inspiraram os cantores da Arte pelo fato de levarem uma vida dissoluta [...]" (p. 33), mas porque "[...] souberam aliar sua beleza física a sua superioridade mental." (p. 34). Em A mãe e a hetera (MOURA, 2005a), Lacerda aprofunda a ideia de que a liberação das amarras institucionais e educacionais, que o sexo produzira na história e continua a produzir, destravaria a cultura milenar que reputa à mulher o papel de mãe e esposa. Libertaria a mulher do "eterno feminino" e possibilitaria a expansão em massa do "terceiro sexo". Sim, haveria o "terceiro sexo", diz ela, formado por "nós as intelectuais" (MOURA, 2005a, p. 67),"as heteras modernas" (p. 66). "Não há motivo para temer o terceiro sexo ou para proibir que a massa feminina ocupe as profissões liberais ou viris." (p. 71). Afinal, "O sexo tem inteligência?" (p. 19) - pergunta Maria Lacerda, com ironia.

\section{O destino indelével do desejo: à guisa de conclusão}

Ninguém imagina um mundo em que a paixão ardente definitivamente pare de nos perturbar [...] Por outro lado, ninguém considera a possibilidade de uma vida eternamente separada da razão. ${ }^{52}$ (Georges BATAILLE, 1997, p. 35).

Em matéria de heterossexualidade, é possível concluir que o anarquista individualista erigiu um discurso contracultural, se considerarmos que a sexualidade legítima era aquela praticada no seio da família monogâmica. Não obstante, a defesa da liberdade sexual não se deu sem contradições. Se o direito ao prazer era fundado na natureza, a qual não deveria ser desvirtuada pelo artifício da monogamia, o anarquista libertário, de modo geral, centrou seu discurso na heterossexualidade. Sob outra feita, melhorar a condição de vida da classe obreira requeria cuidado com a geração da prole, pregando a higiene das famílias, a maternidade consciente e a educação sexual para evitar doenças venéreas e 'taras' sexuais. Ou seja, muitas das concepções sobre a natureza da sexualidade humana e sobre o que é normal ou desviado acabaram por erigir-se em discurso regulador da sexualidade também entre os libertários. Contudo, "[...] para uma ideia tão linda [a do amor livre], sua fragilidade pode ser desculpada." ${ }^{33}$ (BAIGORRIA, 2006, p. 11).

Maria Lacerda, preocupada com a harmonia cósmica, viu na filosofia da vontade de harmonia de Han Ryner e na sua concepção de Amor Plural (com letra maiúscula), instrumentos para a libertação humana. Se para Armand, o problema da posse sexual dos indivíduos estava no amor, nas paixões amorosas românticas, já que o sexo perderia sua simples função reprodutiva, para Maria Lacerda, o amor era o que mais a humanidade precisava; o problema, para ela, estava no sexo, que fossilizou a dependência da mulher. Em Han Ryner ela encontra o verdadeiro sentido do amor. "O Amor é a escada de Jacó: leva-nos ao céu dos nossos sonhos, à iniciação das dores que exaltam, divinizam, redimem, e nos mostra os deuses que aspiram e amam nos templos abertos da nossa religião da realização interior, contínua e harmoniosa [...]" (MOURA, 2005c, p. 155).

\footnotetext{
51 "[...] el derecho a ser dueña de su propio cuerpo, de su voluntad, de sus deseos y de su expansión mental, para vivir la vida en toda la plenitud de sus posibilidades latentes."

52 "Nadie imagina un mundo en el que la ardiente pasión deje de turbarnos definitivamente [...] Por otra, nadie considera la posibilidad de una vida desligada por siempre de la razón."

53 "[...] a una idea tan guapa se pueden excusar sus fragilidades."
} 
Lacerda recebeu críticas de seus contemporâneos quanto à prolixidade, inconsistência teórica e política, imprecisões e contradições (LEITE, 2005). Em 1931, no artigo "¿Un programa? ¿Declaración de principios?", publicado na Estudios, ela rebate às objeções que lhe fazem, aos ataques sistemáticos. "Costumam dizer: 'Maria Lacerda de Moura ainda não se encontrou.' 'Parece que essa senhora não sabe ainda o que quer." ${ }^{44}$ (MOURA, 1931b, p. 13). E ela responde, inspirada no estoicismo de Han Ryner, que não tem mesmo um programa. "Meu programa - que é tal, repito - é a busca incansável de minha harmonia interior, é a 'vontade de harmonia'." 55 (MOURA, 1931 b, p. 15). "Sinto repulsa tanto pelo crime de comandar quanto pela servidão da obediência. Somente a insuficiência mental pode limitar o horizonte de visão da vida." ${ }^{56}$ (p. 16).

Sobre Armand, Diez considera que ele não propôs globalmente novas ideias; dedicou-se a ler, revisar, corrigir, ampliar, difundir e dotar de conteúdos mais tangíveis as teorias de Stirner, e a anunciar, no contexto da sociedade de massa de entre guerras, que "[...] fora do indivíduo não há salvação." (DIEZ, 2007, p. 67). No Prólogo de Individualismo anarquista y camaradería amorosa, afirma-se que é exagerado considerar Armand "um profeta da liberdade sexual". ${ }^{57}$ Ele a praticava e pregava, "[...] mas era uma prédica dirigida a uns poucos, aos companheiros de alma que podiam reconhecer a batida da liberdade em suas ricas formas." ${ }_{8}$ (ARMAND, 2000, p. 2). 0 individualismo de Armand "[...] respondia com um sorriso aos preconceitos tradicionais, um dos quais é o sexual. É o individualismo da alegria. E a alegria é prima irmã do erotismo." ${ }^{59}$ (p. 2).

Não que eu queira a morte do amor, mas tenho medo do amor morto. A esse oponho o amor que vive, que rompe as correntes do preconceito, que arranca a máscara do pudor, que leva tudo com desdém; amor acima do bem e do mal, desencaixado, solto e desenfreado, bêbado, afrodisíaco, silênico, plural, generoso, que não se nega. Oponho-me ao amor pálido, achinelado, limitado, escasso, tímido, ignorante da paixão e da aventura, preso à unicidade como um caracol em sua concha, mesquinho, que não se dá porque há pouco a oferecer. ${ }^{60}$ (ARMAND, 2000, p. 62).

O mito fundante do amor não para de nos inquietar. Os primeiros humanos foram duplos. Mais fortes e completos, os deuses ciumentos da riqueza humana, os cortaram em dois de acordo com sua pobre imagem. Essa divisão criou em nós o amor, a busca inquieta pela outra inquieta metade. São muitos os conceitos criados em torno da palavra amor, mas aqui nos interessou a conjunção amor e sexo, para abordar o princípio do amor livre posto por anarquistas libertários nas décadas de 1920 e 1930. O que se propala hoje como 'poliamor' talvez tenha parentesco com o sonho desses nossos antepassados. Eles desejaram amar várias pessoas ao mesmo tempo, o que não significava apenas ter múltiplas relações sexuais. Apontou para uma nova educação sentimental que acabasse com a posse do corpo e da alma dos indivíduos. Introduziu a prática de comunidade amorosa, de amizade e de companheirismo afetivo. Afirmou que se pode querer bem a dois ou mais seres simultaneamente. Insistiu que se ama a várias pessoas ao mesmo tempo, ainda que com diferentes intensidades e propósitos.

\section{Agradecimentos}

Agradeço a colaboração em pesquisa da doutora Carina Sartori (Université de la Rochelle/ UNESP-Assis) e do mestre em história Daniel Dalla Zen (UFFS). Agradeço também à historiadora Margareth Rago que, no ano de 2003, permitiu-me acessar os livros de Maria Lacerda de Moura de sua biblioteca particular.

\section{Referências}

ARMAND, Émile. "Amor, amor em liberdade, camaradagem amorosa". Tradução Martha Gambini. VERVE: Revista Semestral do NU-SOL - Núcleo de Sociabilidade Libertária. Programa de Estudos

\footnotetext{
54 "Acostumbran a decir: 'María Lacerda de Moura aún no se ha encontrado a sí misma.' 'Me parece que esta señora no sabe todavía lo que quiere.'”

55 "Pero mi programa - que no es tal, repito-, es la busca incesante de mi armonía interior, es la 'voluntad de armonía'."

56 "Me repugna tanto el crimen de mandar como el servilismo de obedecer. Sólo la insuficiencia mental puede limitar el horizonte de visión de la Vida."

57 "[...] un profeta de la libertad sexual".

58 "[... mas éste era un pregón dirigido a unos pocos, unos compañeros de alma que pudieran reconocer el latido de la libertad en sus ricas formas."

59 "[...] con una sonrisa a los prejuicios tradicionales, uno de los cuales es el sexual. Es el individualismo de la alegría. Y la alegría es prima hermana del erotismo."

60 "No es que quiera la muerte del amor, pero tengo miedo del amor muerto. A éste opongo el amor que vive, el que rompe las cadenas del prejuicio, echa abajo el antifaz del pudor, sale al paso desdén; el amor por encima del bien y el mal, desembridado, suelto y desenfrenado, ebrio, afrodisíaco, silênico, plural, generoso, que no se niega. Lo opongo al amor pálido, achinelado, limitado, escaso, timorato, ignorante de la pasión y aventura, pegado a la unicidad como un caracol a su concha, mezquino y que no se da porque es poco lo que pueda ofrecer."
} 
Pós-Graduados em Ciências Sociais, PUC-SP, São Paulo, n. 21, p. 22-29, maio 2012. Disponível em https://ken.pucsp.br/verve/article/download/30715/21243. Acesso em 24/09/2020.

ARMAND, Émile. "El Stirnerismo". La Revista Blanca: Sociología, Ciencia y Arte, Barcelona, ano XII, n. 299, segunda época, p. 781-784, out. 1934a.

ARMAND, Émile. Formas de vida en común sin estado ni autoridad: las experiencias económicas y sexuales a través de la historia. Madrid: Biblioteca de Documentación Social, 1934b.

ARMAND, Émile. "Individualismo anarquista y camaradería amorosa”. Traducción Claudia Piperno. El Ateneu Enciclopédico Popular, Barcelona, 2000.

ARMAND, Émile. "La ley del divorcio". La Revista Blanca: Sociología, Ciencia y Arte, Barcelona, ano V, n. 87, segunda época, p. 687-689, jan. 1927.

ARMAND, Émile. "La lucha por la libertad sexual: 'Los Celos'”. La Revista Blanca: Sociología, Ciencia y Arte, Barcelona, ano XIII, n. 345, segunda época, p. 834-835, ago. 1935.

ARMAND, Émile. "O individualismo anarquista". VERVE: Revista Semestral do NU-SOL - Núcleo de Sociabilidade Libertária. Programa de Estudos Pós-Graduados em Ciências Sociais, PUC-SP, São Paulo, n. 5, p. 208-218, maio 2004. Disponível em https://revistas.pucsp.br/index.php/verve/article/ view/4986. Acesso em 18/01/2018.

ARMAND, Émile. "Pequeno manual do anarquista individualista". Tradução Martha Gambini. VERVE: Revista Semestral do NU-SOL - Núcleo de Sociabilidade Libertária. Programa de Estudos PósGraduados em Ciências Sociais, PUC-SP, São Paulo, n. 11 , p. 123-130, 2007. Disponível em http:/ /revistas.pucsp.br/index.php/verve/article/viewFile/5062/3590. Acesso em 18/01/2018.

ARMAND, Émile. "Prefácio de O Único". In: ARMAND, Émile; BARRUÉ, Jean; FREITAG, Gunther. Max Stirner e o anarquismo individualista. São Paulo: Imaginário, 2003. p. 75-91.

BAIGORRIA, Osvaldo. El amor libre. Buenos Aires: Libros de Anarres, 2006.

BATAILLE, Georges. Las lágrimas de Eros. Tradução David Fernandez. Barcelona: Tusquets, 1997.

CLEMINSON, Richard. Anarquismo y homosexualidad. Madrid: Huerga \& Fierro, 1995.

DIEZ, Xavier. El anarquismo individualista en España (1923-1938). Barcelona: Virus Editorial, 2007.

GARCÍA, Francisco. "La imposible fusión: claves para una genealogía del cuerpo andrógino". In: SOLÍS, D. Romero de; MUÑOZ, Juan B.; LLORET, Jorge L. (Orgs.). Variaciones sobre el cuerpo. Sevilha: Universidad de Sevilha, 1999. p. 217-235.

LEITE, Miriam Lifchitz Moreira. Maria Lacerda de Moura: uma feminista utópica. Florianópolis: Ed. Mulheres; Santa Cruz do Sul: EDUNISC, 2005.

LEITE, Miriam Lifchitz Moreira. Outra face do feminismo: Maria Lacerda de Moura. São Paulo: Ática, 1984.

MARIN, Dolors. Anarquistas: un siglo de movimento libertário em España. Barcelona: Editorial Planeta, 2010.

MOURA, Maria Lacerda de. "A mulher é uma degenerada?" In: LEITE, Miriam Lifchitz Moreira. Maria Lacerda de Moura: uma feminista utópica. Florianópolis: Ed. Mulheres; Santa Cruz do Sul: EDUNISC, 2005a. p. 58-117.

MOURA, Maria Lacerda de. Amai-vos e não vos multipliqueis. Rio de Janeiro: Civilização Brasileira, 1932. Disponível em https://pt.scribd.com/document/367461 144/Amai-vos-e-nao-vos-multipliqueis1932. Acesso em 20/12/2018.

MOURA, Maria Lacerda de. "Autobiografia". In: LEITE, Miriam Lifchitz Moreira. Maria Lacerda de Moura: uma feminista utópica. Florianópolis: Ed. Mulheres; Santa Cruz do Sul: EDUNISC, 2005b. p. 36-46.

MOURA, Maria Lacerda de. "Guerra à guerra". O Combate, São Paulo, n. 4560, p. 3, 19 nov. 1927.

MOURA, Maria Lacerda de. "Han Ryner e o Amor Plural". In: LEITE, Miriam Lifchitz Moreira. Maria Lacerda de Moura: uma feminista utópica. Florianópolis: Ed. Mulheres; Santa Cruz do Sul: EDUNISC, 2005c. p. 135-201. 
MOURA, Maria Lacerda de. "Han Ryner, el Sócrates Moderno". Estudios, Valencia, n. 152, p. 31-32, abr. 1936.

MOURA, Maria Lacerda de. "La concepción ryneriana del amor: el amor plural frente a la camaradería amorosa". Estudios, Valencia, n. 129, p. 22-24, mayo 1934a.

MOURA, Maria Lacerda de. "Los libertarios y el feminismo". Estudios, Valencia, n. 107, p. 15-17, jul. 1933.

MOURA, Maria Lacerda de. “¿Qué es el amor plural?”, Estudios, Valencia, n. 128, p. 24-25, abr. 1934b.

MOURA, Maria Lacerda de. Religião do Amor e da Belleza. São Paulo: Typ. Condor, 1926.

MOURA, Maria Lacerda de. “¿Tiene sexo la inteligencia?”. Estudios, Valencia, n. 100, p. 19-21, dic. 1931 a.

MOURA, Maria Lacerda de. “¿Un programa? ¿Declaración de principios?”. Estudios, Valencia, n. 90, p. 13-16, feb. 1931 b.

NEVES, Barreto das. "Introdução". In: RYNER, H. O Quinto Evangelho. Trad. Maria Angélica de Oliveira. Rio de Janeiro: Germinal, [1961].

REVISTA ANARQUISTA AURORA OBREIRA. n. 48, ano 4, mar. 2015. Disponível em https://anarkio.net/ index.php/2020/07/1 1/revista-anarquista-aurora-obreira-no48/. Acesso em 30/09/2020.

RODRIGUES, Edgar. Os libertários: ideias e experiências anarquistas. Petrópolis: Vozes, 1988.

ROSSI, Giovani. Um episódio de Amor Livre na Colônia Cecília. Tradução Jorge E. Silva. Rio de Janeiro: Achiamé, 2005.

RYNER, Han. "Amor". Tradução Martha Gambini. VERVE: Revista Semestral do NU-SOL - Núcleo de Sociabilidade Libertária. Programa de Estudos Pós-Graduados em Ciências Sociais, PUC-SP, São Paulo, n. 21 , p. 30-36, maio 2012 a.

RYNER, Han. Des diverses sortes d'individualisme. Paris: L'Idés Libres, n. 53, 1922 . Disponível em: https://gallica.bnf.fr/ark:/12148/bpt6k818889/f5.image. Acesso em 30/09/2020.

RYNER, Han. L'Amour Plural. Paris: Éditions Rabot, 1927.

RYNER, Han. La sagesse qui rit. Paris: Les Éditions du Mondo Moderne, 1928.

RYNER, Han. Le crime d'obéir. Paris: La Plume, 1900.

RYNER, Han. Les orgies sur la montagne. Paris: Éditions Eugène Figuière, 1935.

RYNER, Han. Les Pacifiques. Paris: Eugène Figuière, 1914.

RYNER, Han. Manual filosófico do individualista. Tradução Roberto das Neves. Rio de Janeiro: Achiamé, 2012b.

RYNER, Han. Prenez-moi tous! Paris: Èditions du Pambourin, 1930.

RYNER, Han; AUREL, Aurelie Faucamberge Mortier. Le drame d'être deux. Lyon: Les Editions du Fleure, 1924.

SONN, Richard. Anarchism in Interwar France. Pennsylvania: The Pennsylvania State University Press, 2010.

VALENTÍ CAMP, Santiago. La pensadora Maria Lacerda de Moura. Estudios, Valencia, n. 90, p. 11 12, feb. 1931.

VALENTÍ CAMP, Santiago. Las reivindicaciones femeninas. Barcelona: Encarnación, 27 y 29, 1927.

Maria Bernardete Ramos Flores (ppghst@contato.ufsc.br) é Professora Titular Aposentada do Departamento de História da UFSC. Pesquisadora do CNPq 1B. Dedica-se à pesquisa de História e Arte, Modernidade e Estética, Teoria da Imagem e Teoria da História. Publicou, entre outras obras: Tecnologia e estética do racismo: ciência e arte na política da beleza (Argos, 2007); Xul Solar e Ismael Nery entre outros místicos modernos: sobre o revival espiritual (Mercado de Letras, 2017). 
COMO CITAR ESSE ARTIGO DE ACORDO COM AS NORMAS DA REVISTA

FLORES, Maria Bernardete Ramos. "O destino indelével do desejo: o sonho do amor plural entre anarquistas libertários". Revista Estudos Feministas, Florianópolis, v. 28, n. 3, e61583, 2020.

CONTRIBUIÇÃO DE AUTORIA

Não se aplica.

\section{FINANCIAMENTO}

Não se aplica.

CONSENTIMENTO DE USO DE IMAGEM

Não se aplica.

APROVAÇÃO DE COMITÊ DE ÉTICA EM PESQUISA

Não se aplica.

\section{CONFLITO DE INTERESSES}

Não se aplica.

\section{LICENÇA DE USO}

Este artigo está licenciado sob a Licença Creative Commons CC-BY International. Com essa licença você pode compartilhar, adaptar, criar para qualquer fim, desde que atribua a autoria da obra.

\section{HISTÓRICO}

Recebido em 17/02/2019

Reapresentado em 31/10/2019

Aprovado em 09/12/2019

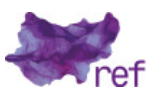

